\title{
“¿Soy papel o soy poeta?”: escritura y muerte en la poesía de Manuel Ramos Otero
}

El siguiente artículo analiza la poesía de Manuel Ramos Otero desde lo que puede ser considerado su eje estructurador central: la muerte. Por medio de un recorrido de los poemarios El libro de la muerte (1985) e Invitación al polvo (I99I) se delinea una parábola que inicia con la muerte del otro y progresa hasta la muerte propia. Este trayecto afecta la posición del hablante lírico, modificando la estructura, las estrategias y el formato de cada uno de los poemarios. Nos servimos de cuatro núcleos temáticos para dar forma al argumento: la invocación inicial (el apóstrofe), el dialogismo y las máscaras del hablante, la función del epitafio y la comunidad, y por último, cómo llegar a un modo de permanencia. El fin de este recorrido es subrayar la especificidad y la función que cumple la poesía dentro del amplio corpus de obras que ha dejado atrás su autor.

Poemas. Objetos de la muerte. Eterna inmortalidad de la muerte. Algo así como un goteo nocturno y afiebrado.

Poesía. Orina. Sangre.

Blanca Varela, El libro de barro

La obra poética del escritor puertorriqueño Manuel Ramos Otero (19481990) consiste en dos poemarios, El libro de la muerte (1985) y el póstumo Invitación al polvo (I99I). Parecería que dentro de la producción amplia de cuentos, ensayos y novela de Ramos Otero, la poesía ha sido relegada de manera automática a un segundo plano, dentro del valioso y nutrido

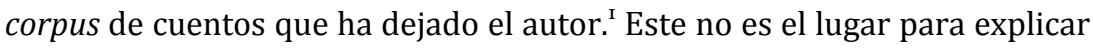
las razones detrás de este espaldarazo sistemático de la crítica al género narrativo, o la resistencia misma de la lírica al análisis crítico. Sin embargo, sí es el momento para declarar que una de las claves de lectura de la obra de Ramos Otero se encuentra justamente en esta parte subvalorada de su producción.

En una entrevista realizada por Marithelma Costa, Ramos Otero afirmaba que "entre los narradores contemporáneos puertorriqueños soy el más cercano a la poesía. Inclusive ese ha sido mi problema con el 
público" (65). La obra lírica del autor se inicia el año que tiene lugar un intento fallido de volver a la isla de Puerto Rico, después de un "sexilio" auto-impuesto en la ciudad de Nueva York que duró desde i968 hasta poco antes de su muerte en 1990 a causa de complicaciones relacionadas con el SIDA (La Fountain-Stokes 892). ${ }^{2}$ De sus comienzos como poeta Ramos Otero comenta: "Empecé a escribir poemas en I977. Vivía en la calle Norzagaray, frente al cementerio y frente al mar. Este era como una gran tumba azul y me daba la sensación de estancamiento. El Libro de la muerte surgió ahí" (Costa 66). La creación de los poemas refleja una rebelión en contra de lo que el autor considera un presente poético lleno de mediocridad, en pleno contraste con una fértil tradición poética nacional, al mismo tiempo que demuestra un sentido práctico de la creación:

Empecé a escribir esos textos por lo mucho que me disgustaba y me disgusta la poesía en Puerto Rico. A pesar de que la Isla ha dado grandes poetas como Palés Matos y Julia de Burgos, también ha dado malos poetas. Hay una proliferación de poetisos, en el sentido peyorativo que tiene la palabra en femenino.

Pero existe otra razón para mis textos poéticos. Como me gusta que lo que escribo llegue a un público amplio y el proceso de publicación es tan difícil, empecé a escribir poesía para poder llevar mi trabajo directamente al público. (66)

Como afirma Juan Gelpí en "La escritura transeúnte de Manuel Ramos Otero", toda la obra del autor puede ser considerada una afrenta contra el canon literario nacional. Es por esta razón que Ramos Otero no duda al establecer su filiación poética con una figura como Julia de Burgos, otra doble marginal (como mujer y exiliada) de la literatura puertorriqueña. ${ }^{3}$

Otra de las características sobresalientes de toda la obra de Ramos Otero es su intención de romper las barreras genéricas: "Mis poemas tienden a ser más teatrales y narrativos, y la ficción más poética. Uso más los feísmos y la cafrería en la poesía que en la narrativa y, hasta cierto punto, es un efecto consciente de mi parte por romper con la idea de que la poesía debe ser una satinada torre de marfil" (Costa 65). En este trabajo quisiéramos ir parcialmente en contra de esta lectura y encontrar cuál es la especificidad de sus poemas más allá de las coordenadas iniciales que hemos visto hasta ahora. Queremos proponer que la poesía de Ramos Otero presenta uno de los núcleos temáticos y estructurales más coherentes de su producción, y estos pueden servir para complementar las interpretaciones ya extensas de su obra narrativa. Pretendemos hacer una lectura diacrónica de El libro de la muerte y de Invitación al polvo, usando como eje conductor el tema de la muerte y el duelo, para demostrar cómo el hacer poético surge a partir de un decir póstumo y de la pérdida. Existe 
una suerte de línea temática persistente en los poemas del escritor puertorriqueño, que consiste en delinear el camino hacia la muerte, un camino en el que, por cierto, se palpan ciertos hitos y posiciones cambiantes. En un primer momento la obra está marcada por la muerte del otro y el proceso de aceptarla, mas la voz poética observa y habla como testigo y sobreviviente. Sin embargo, en una segunda etapa, la muerte se aproxima e invade su propio cuerpo, es decir que la muerte del otro progresivamente se convierte en $m i$ muerte. Esta evolución en la posición del hablante lírico va a afectar la estructura, las estrategias y el formato de cada poemario.

LA INVOCACIÓN INICIAL

En la dedicatoria que da inicio a El libro de la muerte leemos:

a John Anthes

(I945-1982)

ahora más que nunca

mi palabra conjura

tu silencio (7; negrita en el original)

John Anthes, antiguo compañero sentimental del autor, fallece en I982. Su dedicatoria condensa, simultáneamente, varios caminos posibles. El poema celebra la memoria del amado, del otro, ese que no está, ni estará presente de forma material de ahora en adelante; pero el hecho de que este otro no esté, no impide que el poema sea dirigido a él, que él continúe siendo su destinatario. Desde el principio nos encontramos frente a una conversación imposible, aunque necesaria. La palabra conjura el silencio del otro, es decir que la voz poética se sitúa en el presente, en este lado de la vida, y, por medio de su propia voz, de su mero estar vivo, invariablemente desestabiliza el silencio eterno de la muerte. Al conjurar, la palabra (poética) no exige una respuesta, sino que invoca y hace presente. En medio de este proceso, el poeta toma consciencia de que él también tiene un pacto con la muerte que sólo por el momento ha sido diferido. El poema, entonces, está dirigido a, dialoga con y es un pensar sobre la muerte. Exploremos la posibilidad de que esta dedicatoria sea un tipo de manifiesto, un plan de ruta de lo que la poesía puede y debe hacer.

En "Prayer. November IO-15, 1983 (Berkeley)", Philippe LacoueLabarthe propone que existe una relación intrínseca entre la poesía y la plegaria (prayer). Por medio del análisis del poema "Psalm" de Paul Celan, el filósofo francés establece que aunque la plegaria invoca y está dirigida a Dios, este sólo representa lo que es externo a nosotros, un ser 
completamente otro. En consecuencia, al substituir el nombre de Dios por el término nadie (Niemand) en un poema en forma de plegaria, el poeta pone en evidencia la estructura enunciativa que la rige: "It is precisely because the being reveals itself as nothingness, no thing, that the God (someone, einer), reveals himself as not one or none (keiner), and from there as no one (Niemand). A no one whom it is (still) possible to address (you, $d u$ )" (80). Paradójicamente, a partir de la desaparición de la deidad o de la consciencia de esta desaparición, se vuelve posible que el poeta se dirija al otro absoluto que ha devenido el ser. A continuación menciona que: "From nothingness, calling the wholly other, even if he is 'no one', is the very possibility of address, of 'speaking to', of 'saying-you'; the possibility of the poem as the possibility of 're-lating to' in general. And it is in this sense that every poem is a prayer" (84). Así, el poema entendido como invocación, ya no se tiene que dirigir al amante como el ente físico que era, sino que es una apelación al tú que en esencia es lo otro que habita en él. Al invocar, el poeta abre un vaso de comunicación que lo relaciona con el mundo más allá de lo material, y termina, como veremos, creando la posibilidad de comunidad.

La situación enunciativa que evidencia la plegaria en Lacoue-Labarthe está íntimamente relacionada con una figura retórica de uso frecuente en la poesía de Ramos Otero: el apóstrofe. Según Jonathan Culler, el apóstrofe incomoda a la crítica, al punto de evadirlo sistemáticamente, por la dificultad que esta figura crea al enfocar su atención, no en el significado de las palabras, sino en el circuito enunciativo. El apóstrofe es un vocativo que se dirige a un ser inanimado, un objeto natural o incluso una abstracción. Por medio del apóstrofe, el sujeto poético establece un tipo de relación con los objetos, que puede llegar a poner en duda quién o qué es el hablante y quién o qué es el destinatario. La fuerza del apóstrofe está en el hecho de que al dirigirse a este destinatario inanimado lo convierte en sujeto: "apostrophe takes the crucial step of constituting the object as another subject with whom the poetic subject might hope to strike up a harmonious relationship" (63-64). Esta descripción no difiere tanto de la condición de posibilidad de relación que se veía en Lacoue-Labarthe. Culler, empero, describe una etapa adicional posible: esta relación entre uno mismo y el otro puede ser interpretada como un acto de interiorización radical y de solipsismo:

if I implies a you (in that "I" means "your vis-a-vis intends itself"), to name as you that which in its empirical state cannot be a you (such as earth) is a way of preempting the place of the you, placing there what can only fill that role through "an invisible re-arising in us." It is only as a product of poetic intervention that an object 
can occupy the place of the addressee. In this sense, things evoked are objects transformed into internal forces. (66)

Así, por medio del apóstrofe, la muerte, uno de estos objetos inanimados, va a convertirse en una de las fuerzas interiores que maneja el poeta. Esta situación enunciativa la veremos - de una manera u otra - en diferentes permutaciones a través de nuestro recorrido.

DIALOGISMO Y LAS MÁSCARAS DEL HABLANTE

¿En qué consiste el acto de hablar en memoria de alguien? En "Mnemosyne", Jacques Derrida medita en torno a esta pregunta y la relación que establece con el duelo, la memoria, el epitafio y la autobiografía. Según Derrida, cuando hablamos en memoria de alguien estamos llevando a cabo una acción compleja que se inaugura con el duelo posible, un primer movimiento que consiste en la interiorización de la imagen del otro. Cuando el amigo muere y hablamos sobre él, somos conscientes de que no se encuentra más entre nosotros, pero al recordarlo, al dedicar un discurso en su memoria, tratamos de rescatar una parte suya para incorporarla a nosotros. Derrida luego se adentra en un concepto desarrollado por Paul de Man en "Autobiography as Defacement". En su lectura, Derrida afirma que de Man propone analizar la autobiografía y su tropo central, la prosopopeya, para argumentar que "Funerary speech and writing do not follow upon death; they work upon life in what we call autobiography" (22). Según de Man, el género autobiográfico es una manera de ficcionalizar la experiencia propia, confiriendo diferentes máscaras al narrador - de ahí la raíz griega de la palabra prosopopeya (prosopon), conferir una máscara o rostro. La autobiografía deviene un tipo de epitafio que se puede construir en vida, ya que permite al narrador crear una ficción de voz desde ultratumba.

Los poemas iniciales de El libro de la muerte están imbuidos de una cierta teatralidad que, de acuerdo al autor, está relacionada con los estudios que cursó durante los primeros años en Nueva York: "Como había estudiado teatro, estos poemas son altamente teatrales y me sirven para hacer performances con vestuario, luces, props..." (Costa 66; cursiva en el original). En este sentido, no debe sorprender que el elemento más recurrente del poemario sea el uso constante de lo que Arnaldo CruzMalavé ha llamado, refiriéndose a los cuentos de Ramos Otero, "personae, máscaras que se asumen para la investigación del yo que escribe" (240); estas máscaras se encuentran diseminadas a través del texto en las identidades múltiples que va barajando el Yo poético (Tsuchigumo, Nechodoma el vampiro, las poetas Palmira Parés y Marina Arzola, el 
travesti Gilbert Robbins y Carmen Ana Otero). De igual importancia es el constante cambio de máscaras que se ve en la estructura misma de los poemas: se observan quiebres frecuentes, transformaciones e irrupciones dentro del fluir de los textos, tal como si hubiera una lucha por mantener la unidad de voz en el poema, que está inevitablemente destinada a fracasar por causa de la filtración de voces exteriores.

"Esta es la segunda parte del Ulysses" comienza con varios versos de tono exotizante que sirven como trasfondo y dan paso, en la segunda y tercera estrofas, a un intruso en el entrecomillado que anuncia a Tsuchigumo. Llama mucho la atención el uso del entrecomillado en un poema, particularmente porque este funciona como una cita, otra voz que se inserta en el texto y crea una instancia dialógica más cercana al discurso narrativo que al discurso poético. La aparición histriónica de Tsuchigumo, como una puesta en escena teatral, es enunciada así por una vox populi que canta su segunda muerte y describe la procesión que lo lleva camino al cementerio. Es notable el efecto del vestuario, la utilería y el performance que menciona Ramos Otero:

"Tsuchigumo ha muerto de nuevo por la tarde

van bajando su entierro con faroles de papel

camino al cementerio de mármol italiano de San Juan".

"¿Que Tsuchigumo ha muértose otravez

lo vieron bajar con su kimono de bromelias

y dos espejos negros cubriéndole sus ojos de vinagre!" (Io; comillas en el original)

Este apóstrofe es seguido rápidamente en la cuarta estrofa por un cambio de focalización hacia un yo: "El café japonés ya no me sabe / Mi balaustrada casa frente al mar es de papel" (Io). Esta voz frente al mar será la que va a dar forma al poema. La proximidad que tiene "Esta es la segunda parte del Ulysses" con la dedicatoria podría sugerir que Tsuchigumo representa al amante que ha partido recientemente. Lo que permanece después de su entierro no es esta figura de otredad, el geisha, sino la voz que transita un luto posterior. Hacia el final, sin embargo, encontramos una segunda posibilidad interpretativa que se relaciona estrechamente con el performance y la máscara. En los últimos versos leemos: "los faisanes fugaces queriéndose quemar detrás del mar / sin que nadie sospeche en el sepelio / la malacostumbrada soledad" (II). Por la manera en que la malacostumbrada soledad se revela como la causa detrás del espectáculo del entierro se podría asumir que Tsuchigumo es más bien una proyección de la voz, ya que el hablante sabe lo que ocurre en el 
interior del otro personaje. Si bien la máscara crea un sentimiento de inestabilidad y separación entre los dos focos narrativos, es posible pensar que esta distancia no es tanto real sino ilusoria: la máscara, como propone Cruz-Malavé, se utiliza para explorar los confines de ese yo que escribe.

El "Epílogo" al final de El libro de la muerte comienza: “¡AL FIN HA LLEGADO METCALF!” (64). Este despliegue hace pensar que los poemas previos no han sido más que un preámbulo, una larga espera para concretar el encuentro deseado con el amado. Pero hay, todavía, un obstáculo: la aparición del amante sólo puede ocurrir en el escenario de un sueño que transciende los límites del tiempo histórico. Esta invocación de Metcalf cumple una de las funciones del apóstrofe que menciona Culler en el poema; la relación que el yo establece con esta imagen ayuda a romper con la temporalidad de la narrativa y crea una temporalidad de la escritura:

In lyrics of this kind a temporal problem is posed: something once present has been lost or attenuated; this loss can be narrated but the temporal sequence is irreversible, like time itself. Apostrophes displace this irreversible structure by removing the opposition between presence and absence from empirical time and locating it in a discursive time. The temporal movement from A to B, internalized by apostrophe, becomes a reversible alternation between $A^{\prime}$ and $B^{\prime}$ : a play of presence and absence governed not by time but by poetic power. (67)

En efecto, Metcalf está muerto y quien aparece no es más que otra imagen que proyecta el Yo poético. Como imagen, Metcalf es el hilo conductor, la constante que une la voz con su versión más joven: "Metcalf no pertenece al mundo. / Metcalf es nuestro - él y yo -" (64). Los deícticos - él y yo -, en este caso, se refieren tanto al Yo pasado ("el niño remoto del bastón de arena que pactó por sus nupcias / con Metcalf" [64]), como al Yo presente, el que invoca a través del recuerdo y de la escritura; ambos se encuentran en ese nuestro, que se forma a partir de la figura del amante. Metcalf no pertenece a este mundo porque no es el cuerpo físico, el que se ha ido indefectiblemente para no volver, sino que es la imagen de él que intenta fijar el poema.

A través de todo el texto la voz está consciente de la futilidad de su gesto, ya que llama en múltiples ocasiones a Metcalf sin recibir contestación alguna. Pero aún así, hay una cierta compulsión por volver a esta imagen, por intentar comunicarse con ese tú, porque su búsqueda funciona, en última instancia, como parte de un proceso inacabado de aprendizaje: 
Yo ayudo a Metcalf a caminar tranquilo

lo reto a reflejarse en un espejo

y veo que su imagen su duplica [sic]

mientras yo sigo siendo el que no veo

el cambio extraordinario en la fortuna

y el carácter fugaz de la memoria. (64)

El que ha partido ya no sufre más ni está dentro del ciclo inacabable del rememorar en que se encuentra el hablante. Esto no quita que sea el disparador en la consciencia de ese Yo que habla, el que lo lleva a cuestionar su propia vida y la memoria por medio del poema. Es evidente que la imagen inicial del otro está sujeta en parte al deseo del Yo que la produce, por eso lo acompaña, aunque sea sólo por un instante. El resto de las veces, el amante sólo será una invocación de otredad, una plegaria en el sentido de Lacoue-Labarthe. Habrá una vuelta reiterada al recuerdo de encuentros previos y su iniciación, con un único fin en mente: "Donde comienzan el cuerpo y el poema, / reclamarás la fuerza intestinal para los comensales de tu ombligo. / Soñarás cuando quieras con Metcalf y sólo soñarás" (65). El cuerpo que intenta desenterrar en la memoria y el cuerpo del poema son uno, son una búsqueda desenfrenada por el otro.

El final del poema se acercará de nuevo a la reflexión sobre la muerte, el amante y su presente imposibilidad de dejarlo ir: "Estoy aquí, Metcalf. / Arrodillado estoy en el recuerdo. / He venido a tu carne como al río" (66). $\mathrm{Al}$ volver sobre esta figura se la asocia con el vaivén del mar, como si estuviera atrapado en un tipo de circularidad que lo lleva inevitablemente a pensar en él. Los últimos versos están plagados de una cadena de significantes que remiten al agua, al movimiento: río, mar, bahía, costa. El agua puede apuntar en dos direcciones: por un lado, está asociada al mismo movimiento de rememorar, a su ir y venir; pero además puede estar asociada a la imagen misma de Metcalf, en particular el efecto del olvido que va desgastando su imagen con el pasar de los años ("A veces el cáncer hace tan neblinosa tu figura" [67]). Llamar a Metcalf es ineludible, por más que ya haya desaparecido. El hablante invoca la imagen de su cuerpo, la imagen que existe en el interior del poeta, como parte del acto de resistencia que representa fijarlo en el poema.

EPITAFIO Y COMUNIDAD

Hasta aquí hemos visto que este canto a la muerte está dirigido en principio al amante fallecido. Pero además, ahora encontramos una serie intitulada "Epitafios" incluida en El libro de la muerte. Cada poema de esta 
sección establece un diálogo imaginario con poetas y escritores que han influenciado la obra del autor. Efraín Barradas propone que aquí:

Ramos Otero trata de crearse un pasado poético personal para decirnos de dónde ha surgido, o mejor, de donde hubiera querido haber surgido. Pero ese plan de acción individual es también un esfuerzo colectivo. Tal actitud es típica y necesaria en el proceso de auto-definición de todo grupo minoritario. El intento de creación de un pasado homosexual, pues, no puede sorprendernos. (324)

Ramos Otero intenta delinear un mapa universal de sus influencias literarias, y en el proceso, construir su propia genealogía como poeta homosexual. Al dedicar un epitafio se relaciona en varios niveles con su contraparte: en primer lugar expresa una admiración por su escritura, su estilo, su obra, pero además, y probablemente más significativo, torna presente el cuerpo del que habla. Lo que en primera instancia parecería ser un acto para enaltecer la figura que admira, en muchas ocasiones da paso a un encuentro erótico.

El afán genealogista de Ramos Otero es constante a través de toda su obra. En "Genealogías o el suave desplazamiento de los orígenes en la narrativa de Manuel Ramos Otero", Aurea María Sotomayor ha delineado cómo se expresa esta intención en "Vivir del cuento" del libro Página en blanco y staccato. El genealogista no es solamente la persona que intenta trazar los orígenes, sino que es "el que descubre esos fundamentos y los somete a una crítica, a diferencia de un juez, que acata el valor o la norma independientemente de su fundamento" (280). Este es el cuentero que asume Ramos Otero: el que reorganiza y reinterpreta la tradición y todas categorías que se dan por sentadas; en el caso del cuento, el narrador dispara contra las "quimeras del origen que son la clase, el sexo, la familia, la nación" (280). Para los efectos de nuestro argumento, quisiéramos concentrarnos en cómo Ramos Otero diseña sus orígenes a partir de la memoria del exiliado, y especialmente cómo lo hace desde la figura del poeta.

Acerquémonos al poema "Kavafis" de los "Epitafios", primo distante del famoso "Ítaca" del escritor griego Constantino Cavafis. En el centro del poema de Cavafis late la preocupación por el regreso a la tierra natal, pero el énfasis siempre está puesto sobre el camino a recorrer y las experiencias que puede producir esta travesía. Si bien Ítaca es el destino final, sólo es una excusa para emprender el viaje y enfrentarse a los demonios internos del sujeto. "Kavafis" arranca con un regreso también, sin embargo, este toma un nuevo significado por la carga emotiva que le añade el estado del exilio en el imaginario puertorriqueño. El exilio representa la experiencia 
límite inicial en Ramos Otero, el umbral a cruzar para ser otro, liberado de la opresión de la cultura machista caribeña. ¿Qué es el exilio sino la primera muerte a la que se enfrenta el poeta?

El peligro inherente del viaje mítico en el poema de Cavafis desaparece en la versión de Ramos Otero; su vuelta se encuentra desprovista de aventura en el sentido clásico, aquí el retorno es un proceso de crecimiento, una apertura que apunta más bien a la aventura sexual:

Piensa, que ningún compañero compartirá tu soledad,

que la ciudad te amó y entre sus ruinas fuiste

espíritu de luz, sin haber estado muerto,

y de noche fue tuyo el cuerpo de la noche.

No temas al Ángel que cada madrugada

dejó sobre tu cama las palabras prohibidas

que te hicieron poeta,

tu corazón siempre ha sido azul de mar

y sus sirenas no quieren tu naufragio. (59)

Es importante notar que la ciudad en la que el poeta se sumerge está puesta en un plano de igualdad con los amantes físicos. Al igual que estos, la ciudad es el lugar que libera, el encuentro clave que permite el crecimiento del poeta. Pero la ciudad también simboliza su condena, ya que representa la pérdida y posibilita el intento de rescatar la experiencia en el plano de la memoria. Esta aproximación a la ciudad tiene muchos paralelos con cómo se codifica el amor en Ramos Otero: desde la ruina. Siempre se escribe desde un momento posterior a la pérdida, cuando la inmediatez de la experiencia ya ha pasado a la memoria. El amor, entonces, se escribe en pasado. Esta arqueología forma parte de un proceso clave, porque sin ella no sería posible la poesía: "No temas al Ángel que cada madrugada / dejó sobre tu cama las palabras prohibidas / que te hicieron poeta" (59). La experiencia erótica y la experiencia citadina se combinan para dar paso a las palabras prohibidas. Si osamos llamarlas de otra manera, estas no son más que la palabra poética, esa palabra arriesgada que no puede ser pronunciada en otro lugar que en ese afuera. Por esta razón, "el exilio ha sido generoso contigo" (59), no por haber tratado particularmente bien al sujeto, sino por ser al mismo tiempo su condena y la condición de posibilidad del florecer del poeta.

A pesar de esta necesidad de espacio, de una distancia impuesta, siempre hay algo que llama a volver. Hay un regreso a Borikén, pero éste debe ser pausado y tendido, como la vuelta a Ítaca. Antes que una vuelta física, no obstante, hay una vuelta a las imágenes, a lo sensorial, a la niñez. 
La imaginación es el vehículo con el que primero se llega al perfume de los flamboyanes, al agua de parchas, a las cuevas escondidas en cualquier playa, que reaniman la vida pasada. Después de tan larga travesía, cuando finalmente toca tierra, el tono del hablante poético, aún siguiendo el modelo de la voz en Ítaca, adopta una postura más combativa:

Y si al llegar, Borikén es la misma

que te obligó al exilio, sacrifícala;

sólo de cuna y tumba te ha servido la tierra,

y entre ambas, un hombre entre los hombres

ha cultivado arrugas en la nada. (6o)

El fin del viaje en el poema de Cavafis representa el proceso de aprendizaje en su totalidad. Al llegar al destino por fin se aprende que todo está cifrado en el viaje, y no en una esencia que emana mágicamente del lugar al que se vuelve. Lo que aparece finalmente es la posibilidad de desarrollar una mirada crítica, diferente, desmitificadora. El proceso de aprendizaje en el poema de Ramos Otero, además de estar impregnado con este nuevo conocimiento, le da una doble potencia a la voz poética: consigue la fuerza para sacrificar la imagen de esa isla que desencadenó el exilio, es decir, de destruir una imagen perjudicial a la psiquis del sujeto, y lo lleva a la construcción de un nuevo centro, su Borikén.

En Invitación al polvo también encontramos una continuación al motivo del epitafio. Recordemos que, en un principio, el poemario explora en detalle la connotación popular del título: la temática de la sección "Del polvo enamorado" se enfoca en el rescate de antiguos amores y encuentros sexuales. Los últimos poemas de esta sección se acercan cada vez más a "La víspera del polvo", donde habrá un giro temático que lo aproximará más a su connotación escatológica. Se puede intuir que esta progresión hacia el polvo apunta hacia la disolución del cuerpo. ${ }^{4}$ No obstante, cabe la pena preguntar cuáles son las estrategias que emplea el hablante lírico para enfrentar la inminencia de este estado. Es por esta razón que llama la atención que sea en el momento previo a "La víspera del polvo" cuando el poeta decide retomar la imagen del cementerio y el epitafio. Veamos la metáfora prolongada que da inicio al poema " 28 ":

Ustedes verán caer a la hora del crepúsculo la casa.

Aunque flota sobre el mar las olas no apagarán sus llamas.

No hay polilla que carcoma sus jorcones, ni neblina que

apacigue su aliento. La casa quema su corazón contento.

Si piensan que este fuego es un suicidio, deténganse 
a pensar quién es el muerto: aquél que libera sus heridas

o aquél cuya vida es el silencio. ¿Qué loco sufre más?

¿Aquel que asume a plenitud su sanatorio o aquél que visita

la locura los domingos? (38)

Estamos frente al crepúsculo, cerca del final. Hay un aire generalizado de muerte que se enfrenta a un tipo de resistencia; la casa en llamas está siempre al borde de la destrucción, del desastre, pero se mantiene firme, flotando, viva. De hecho, se puede decir que esta llama se nutre de la inminencia de la catástrofe. La casa es lo que late en el corazón del hablante poético, la poesía misma. Otros, desde afuera, podrán interpretar esta llama como un tipo de suicidio o el castigo de la locura, sin embargo, es justamente su reverso; esta llama es la que da fuerza a la creación, además de ser la llama que da permanencia al poeta. El hacedor de poesía no es un loco cualquiera, no es la persona que vive abstraída y enajenada, sino que es el que asume su locura como propia, como beneficiosa, como una apertura a otro estado.

Para nuestro argumento resulta central que en medio del proceso de resistencia la voz poética se asuma finalmente como poeta, como alguien diferente y separado de los demás, ese Ustedes del que habla. Dicho de otro modo, aquí la voz se hace cargo del lugar que debe ocupar y de la responsabilidad que le toca en el mundo. "La casa vuelve al polvo de sus versos, biblioteca de huesos / Sus huéspedes velamos con amor la dulce decadencia de su tiempo" (38). En este caso no hay que pensar la muerte como el final solitario y absoluto al que estamos acostumbrados, porque al morir, al devenir polvo, el hablante lírico se reconoce como parte de una comunidad. El hacedor de poesía individual muta y se convierte en Sus huéspedes velamos, este giro hacia un nosotros apunta subrepticiamente hacia el ingreso de la voz en el espacio de lo común.

Es en este punto que se vuelve nuevamente al epitafio. La voz poética rinde homenaje a una genealogía literaria, haciendo alusión a cada autor con su nombre propio y un elemento reconocible de su poesía. Desde César Vallejo a Julia de Burgos, de Edgar Allan Poe a Kavafis, todos están presentes, pero definitivamente algo ha cambiado desde que estos aparecieron en los "Epitafios" de El libro de la muerte. En esta ocasión, los poetas forman parte de una comunidad física e imaginaria: "Cuando los elementos reclamen su lugar, ustedes clavarán en el / polvo: 'Cementerio de poetas. Bienvenidos'” (38). Sus versos han dado forma a una biblioteca universal, un espacio de reencuentro que simultáneamente cumple la función de cementerio de poetas. No hay que olvidar dos cosas, sin embargo. Primero, que la condición para entrar a este espacio se enfatiza 
con el quiebre del verso, la caesura: el polvo. Sin una vuelta al polvo, sin un abrirse a la muerte, el poeta no puede ganar un lugar en esta cofradía. Segundo, como ya hemos mencionado, la voz se ha distanciado del ustedes, de los que clavarán un letrero en el polvo y celebrarán a los poetas en el futuro, lo que enfatiza un cambio de posición en el hablante. A diferencia de los "Epitafios", donde la voz admiraba a otros e intentaba entablar una relación cuerpo-a-cuerpo con ellos, el poeta ahora declara, de una vez y por todas, formar parte de ese grupo selecto. La especificidad del género lírico en el sistema de escritura de Ramos Otero pasa por la posibilidad de transitar del sujeto individual a una relación en comunidad con estas otras voces. En otras palabras: frente al umbral de la muerte, cerca del desvanecimiento del cuerpo, el Yo poético de “28” decide afirmar su lugar como creador y enfatizar la permanencia de la casa que da inicio al poema: la llama infatigable de la poesía.

ESCRITURA, MUERTE Y POSTERIDAD

Tanto en poesía como en prosa, Ramos Otero se esfuerza por problematizar la línea divisoria entre la realidad y la ficción. Con esta aclaración queremos afirmar que el leve tono autobiográfico de su escritura está presente en mayor o menor escala desde el principio; aún así, la presencia general de un Yo autobiográfico y el intento de plasmar la experiencia íntima de la enfermedad del autor en la "La víspera del polvo" sin duda fortalece drásticamente este vínculo. En este momento de la producción se vuelve sumamente difícil divorciar la experiencia que se plasma en los poemas, la sentencia de muerte, de la autobiografía de Ramos Otero.

El epitafio, ya hemos dicho, puede tener una doble naturaleza. En el comienzo exploramos un primer movimiento interiorizante: cuando se muere el amigo queremos preservar una imagen de él ante su desaparición física. Esta imagen no tiene nada que ver con la persona; como dicta la palabra misma, es una imagen que creamos para recordarlo, para hacernos creer que permanece una parte suya dentro de nosotros. Pero, ¿qué pasa cuando el que desaparece no es el otro, sino yo mismo? ¿Cómo enfrentar mi propia partida? ¿Cómo crear una imagen que permanezca a pesar de la muerte? Es aquí que entra en juego la autobiografía, ese otro movimiento del epitafio que optamos por denominar su función exteriorizante.

El discurso autobiográfico crea la posibilidad, aunque sea en el lenguaje mismo, de simular la experiencia de la muerte. Dicho de otro modo, lo que está en juego en este tipo de discurso es una ficcionalización de la experiencia interior. El mecanismo central aquí es un desdoblamiento, o lo que Derrida denomina un tipo de alucinación 
esquizofrénica, que apunta hacia el horizonte que trazamos desde el inicio: "The selbst, the soi-même, the self appears to itself only in this bereaved allegory, in this hallucinatory prosopopeia-and even before the death of the other actually happens, as we say, in reality" (28-29). Por medio del discurso autobiográfico, la muerte propia es representada de modo similar al de la muerte del otro: se crea una imagen de esta, que no corresponde del todo con la real, y se exterioriza para distanciarla y procesarla de manera a priori.

El penúltimo poema de Invitación al polvo se titula "La rosa". La muerte, más inminente que nunca, ha sido aceptada por el hablante. El poeta, ese que ha estado fascinado con la muerte desde un tiempo inmemorial, conoce mejor que nadie su propio destino. No falta mucho para que el cuerpo desaparezca y se fije la obra, el objeto por el cual ha luchado hasta el momento. Ahora más que nunca, el poema funciona como testamento, porque la única resistencia, la huella que permanece es el lenguaje. El poema comienza con los siguientes versos: "El martes que viene voy de viaje. / No es necesario hablar de mal agüero. / Regreso al pan, al mar y al aguacero. / A humedecer con polvos mi homenaje" (64). La imagen del viaje que da inicio al poema, la partida, matiza la connotación negativa de la muerte, en especial esta muerte destructiva y fulminante causada por la enfermedad que invierte doblemente la imagen de la rosa. Las heridas, el cáncer de sarcoma, se tornan flores, heridas abiertas que la voz aproxima al régimen estético. El cuerpo del poeta regresa al origen, a ese polvo del que vino, pero las imágenes que escoge para ilustrarlo apropian la muerte como parte de un proceso necesario. La partida, en definitiva, es clave para la permanencia: el homenaje es la obra que quedará detrás del poeta, y su muerte, la condición de existencia y el horizonte que le da significado.

A pesar de la inevitabilidad de la muerte, hay una mirada retrospectiva sobre la vida dedicada a la poesía y al amor carnal, que no pide perdón por nada:

No hay que pedir perdón por el placer del alma ni conciliar la falsa compasión de los heridos, hoy más que nunca la llaga es una rosa hoy más que nunca la rosa es un pretexto ¿Qué más quieren de mí sino este libro abierto que a todos asegura el clímax de sus penas, este fúnebre ramo deshojado, este mapa de piel que profetiza la órbita de otra cuarentena? (64) 
Aquí observamos el discurso autobiográfico en su nivel más autoconsciente. El poema es el lugar que permite procesar la experiencia personal, es decir, ese sufrimiento y desencanto con la sociedad que ha condenado al enfermo al ostracismo, transfigurada en imágenes. La enfermedad del poeta es una realidad material por la que pasa el cuerpo. Sin embargo, el mecanismo de su representación es mucho más complicado de lo que parece. El poema es la escenificación del sufrimiento, ese libro abierto al alma del poeta que lo deja todo plasmado en el lenguaje.

El esfuerzo condensado por cuestionar la muerte que obsesionó al poeta es evidente en " 7 "; quizás este poema sea el que mejor cristaliza la función del epitafio en Ramos Otero. “¿Quién habrá inventado a Dios y al demonio del amor, / a la herencia de la muerte, a la apariencia que dura / como si fuera la cuna de la vida y de la suerte?" (I6). Una pregunta retórica lanzada al vacío nos introduce en el campo de los grandes cuestionamientos de occidente: la deidad, el amor, la muerte, la permanencia. Es decir, un apóstrofe que lo despersonaliza a él, al mismo tiempo que lo pone en relación con ese otro tú despersonalizado.

En este caso la asociación principal de la voz poética es precisamente con su condición de poeta: "Yo también quisiera hijos si no es porque soy poeta / y mis hijos son palabras que crecen sobre el papel. / ¿Soy papel o soy poeta?, se ha preguntado mi alma / en la cruel y eterna noche del mar que jamás se calma" (I6). Frente a la muerte, ya lo hemos mencionado, el poeta se reconoce poeta, y refuerza el poder de su creación, su manejo de la palabra. Ya se ha ingresado de algún modo al cementerio, a la biblioteca, a la posteridad encarnada en sus versos; por esta razón el alma se pregunta “¿Soy papel o soy poeta?”, porque ya no sabe distinguir en el tránsito hacia la muerte, si es uno o si es lo otro. Lo cierto es que esta dicotomía, esta conjunción disyuntiva, resulta falsa: la voz ahora es tanto papel como poeta. Paradójicamente, el rescate de la voz que susurró estos versos se da por medio de un proceso, la escritura, que es en sí mismo un tipo de muerte: la voz viva del poeta, su palabra, es traspuesta al papel, a la letra muerta. En última instancia, la violenta quietud del poema cristaliza dos posibilidades: la vida y la muerte. “¿Y qué haré cuando esté viejo y los que amé se hayan muerto / o qué si muero esta noche y aquel que me amó perdura?" (I6); ésta puede ser la cifra de la obra poética de Ramos Otero, la poesía según la entiende nuestro poeta y según la hemos explorado en este trabajo. Por un lado, para crear el poema, para darle vida, el poeta tiene como única condición que estar del lado de los vivos. Si la muerte ataca el cuerpo del otro, la creación usa como base este evento para llevar a cabo una búsqueda obstinada por rescatar una imagen que permanezca frente a la desaparición. Si la muerte ataca el cuerpo propio, no queda otra opción 
que perdurar en su creación, en los versos que ha dejado. Esto es otra forma de decir que desde un inicio hay un intento de permanencia en la comunidad, en el ser en común del poeta y su relación con lo otro.

\section{University of Pittsburgh}

\section{NOTAS}

I Ramos Otero da inicio a su producción con el libro de cuentos Concierto de metal para un recuerdo y otras orgías de soledad (1971), seguido por la novela titulada La novelabingo (1976), el libro de cuentos El cuento de la Mujer del Mar (1979), el poemario El libro de la muerte (1985) y el libro de cuentos Página en blanco y staccato (1987). Póstumamente se publica el poemario Invitación al polvo (1991) y las antologías Cuentos de buena tinta (1992) y Tálamos y tumbas. Verso y prosa de Manuel Ramos Otero (1998).

2 El término sexilio es utilizado por La Fountain-Stokes para referirse al exilio debido a la intolerancia sexual; el autor toma el concepto de los escritos de Manuel Guzmán y los filmes de Frances Negrón Muntaner e Irene Sosa. Para leer más sobre las condiciones del exilio en Ramos Otero referirse a Costa 5960 .

3 Julia de Burgos (I9I4-1953) es la autora de los poemarios Poema en veinte surcos (1938), Canción de la verdad sencilla (1939) y el póstumo El mar y tú (I954). En "El sujeto nómada en la poesía de Julia de Burgos", Juan Gelpí propone que la escritura de la poeta y su recorrido de vida encarnan un modelo alternativo al canon sedentario del nacionalismo cultural. La figura central de esta vertiente, el ensayo de interpretación nacional Insularismo (i934), de Antonio S. Pedreira, tiene una visión “[f]undamentalmente nostálgica y orientada hacia una temática de la tierra, esa literatura es también hispanófila, y uno de sus ejes obsesivos es la identidad nacional o cultural; en ella ni abunda ni se tolera la ambigüedad" (248). Frente a esta tradición, la poesía de Julia de Burgos compone una "línea de fuga" (249) por tres razones: I) su elección del género lírico como modo de resistencia ante un canon paternalista que sólo reconoce los géneros de la novela y el ensayo de interpretación histórica; 2) el despliegue de un sujeto nómada "-efecto creado en los poemas-" (252); y 3) el exilio literal (La Habana y Nueva York) y metafórico (fuera de los espacios culturales hegemónicos de la época) de la poeta. En este sentido, el legado de Julia de Burgos representa un gran antecedente de la escritura de Ramos Otero.

4 Resulta muy sugerente la referencia intertextual que establece aquí Ramos Otero con el poema de Quevedo, "Amor constante, más allá de la muerte"; en 
especial, si tenemos en cuenta tanto el motivo del epitafio, como el tema de nuestro próximo apartado "Escritura, muerte y posteridad". En ambos es sumamente notable la perenne tensión entre Eros y Tánatos, es decir, la pulsión de vida/muerte y la creación de sentido.

OBRAS CITADAS

BARRADAS, EFRAín. "Epitafios: el canon y la canonización de Manuel Ramos Otero".

La Torre 27-28 (1993): 319-38.

costa, marithelma. “Entrevista con Manuel Ramos Otero”. Hispamérica 20.59

(I99I): 59-67.

CRUZ-MALAVÉ, ARNALDO. "Para virar al macho: La autobiografía como subversión en la cuentística de Manuel Ramos Otero". Revista Iberoamericana 59.I62 (1993): 239-63.

C Uller, Jonathan. "Apostrophe”. Diacritics 7.4 (1977): 59-69.

DER RidA, JAC Qu Es. "Mnemosyne”. Memoires for Paul de Man. Trad. Cecile Lindsay, Jonathan Culler y Eduardo Cadava. New York: Columbia UP, 1986.

GELPí, JuAN. "El sujeto nómada en la poesía de Julia de Burgos". Revista de Crítica Literaria Latinoamericana 45 (1997): 247-60.

—. "La escritura transeúnte de Manuel Ramos Otero". Literatura y paternalismo en Puerto Rico. San Juan: Editorial de la Universidad de Puerto Rico, I993. 174-92. LA FOUNTAIN-STOKES, LARRY. "Entre boleros, travestismos, y migraciones translocales: Manuel Ramos Otero, Jorge Merced, y El bolero fue mi ruina del Teatro Pregones en el Bronx". Revista Iberoamericana 71.212 (2005): 887-907. lacoue-labarthe, Philippe. Poetry as Experience. Trad. Andrea Tarnowski. California: Stanford UP, I999.

ramos otero, manuel. Invitación al polvo. Puerto Rico: Plaza Mayor, 2013. -. El libro de la muerte. Puerto Rico: Editorial Cultural, 1985.

SOT OMAYOR, AUREA MARía. "Genealogías o el suave desplazamiento de los orígenes en la narrativa de Manuel Ramos Otero". Femina Faber. Letras, música, ley. San Juan: Ediciones Callejón, 2004. 279-306. 